Barbara Jaworska-Dębska*

\title{
WSPÓŁDZIAŁANIE JEDNOSTEK SAMORZĄDU TERYTORIALNEGO W WYBRANYCH FORMACH PUBLICZNOPRAWNYCH A ICH SAMODZIELNOŚĆ
}

Rozważania na temat decentralizacji we współczesnej administracji publicznej nie pozwalają na pominięcie samorządu terytorialnego, który realizuje zadania publiczne na zasadach względnej samodzielności. W związku z tym można się zastanawiać, czy realizacja tych zadań przez jednostki samorządu we współdziałaniu, w szczególności gdy ma ono charakter obligatoryjny, rzutuje w jakiś sposób na zakres owej samodzielności i czy jej ewentualne ograniczenia mają racjonalne podstawy, czy też nie naruszają one zasady proporcjonalności.

1. Czyniona w tym miejscu konstatacja, że organy administracji - zarówno jednolitej administracji państwowej istniejącej do 1990 r., jak i organy współczesnej, dualistycznej administracji publicznej, w tym organy samorządu terytorialnego - nie są w swoim działaniu osamotnione, że nie działają one, i nie muszą działać, wyłącznie „w pojedynkę", nie jest odkrywcza, jednakże zważywszy temat opracowania, jest - jak się wydaje - uzasadniona. Na przestrzeni lat przyjmując

Barbara Jaworska-Dębska - doktor habilitowany nauk prawnych, profesor nadzwyczajny UŁ, Zakład Prawa Samorządu Terytorialnego Katedra Prawa Administracyjnego i Nauki Administracji, Uniwersytet Łódzki. 
różne formy i zakres podmiotowy, współdziałanie administracji i w administracji ma bowiem długą tradycję. Istniało zarówno w warunkach jednolitej administracji państwowej ${ }^{1}$, jak też istnieje - choć w zasadniczo odmiennych formach - współcześnie, w tym głównie w samorządzie oraz z jego udziałem.

Odnosząc się do samorządu terytorialnego, można wręcz postawić tezę, że właśnie ten segment władzy publicznej, charakteryzujący się brakiem powiązań między jednostkami samorządu terytorialnego (brakiem zależności i zwierzchności), jest przede wszystkim predestynowany do współdziałania, jest wręcz do niego stworzony. Współcześnie samorząd terytorialny w znacznym stopniu i zakresie opiera swoje działania właśnie na szeroko rozumianym współdziałaniu, ujmowanym jako rodzaj więzi zbliżonej do koordynacji, występującym jedynie w układzie zdecentralizowanym² ${ }^{2}$ Współdziałanie łączy bowiem podmioty niezależne od siebie, pomiędzy którymi brak organizacyjnego, hierarchicznego podporządkowania. Biorąc pod uwagę to istotne uwarunkowanie współdziałania, należy podkreślić, że w systemie jednolitej administracji państwowej zbudowanej za zasadzie hierarchicznego podporządkowania - nie licząc współdziałania przy podejmowaniu decyzji administracyjnych - w zasadzie nie mieliśmy do czynienia ze współdziałaniem w administracji we współczesnym wymiarze, gdyż podmiotami tego współdziałania były tylko hierarchicznie powiązane organy administracji państwowej, natomiast występowało współdziałanie administracji z innymi podmiotami, głównie z podmiotami społecznymi ${ }^{3}$. Aktualnie w dualistycznej administracji publicznej współdziałanie, którego podmiotami są wyłącznie jednostki samorządu terytorialnego, jest nie tylko możliwe, ale też bardzo popularne. Poza tym ma też miejsce współdziałanie

${ }^{1}$ Por. np. W. Dawidowicz, Wstęp do nauk prawno-administracyjnych, Warszawa 1974; A. Grala, Wpływ władz miejskich i gminnych na kompleksowy rozwój ich terenu, „Problemy Rad Narodowych” 1979/44; B. Jaworska-Dębska, Współdziałanie organów władzy i administracji państwowej z organizacjami społecznymi w dziedzinie kultury fizycznej i turystyki, „Problemy Rad Narodowych” 1987/70.

2 J. Zimmermann, Prawo administracyjne, Warszawa 2016, s. 231.

3 Por. np. M. Wierzbowski, Współdziałanie rad narodowych $z$ organizacjami społecznymi, „Gospodarka i Administracja Terenowa” 1971/4; J.M. Lang, Współdziałanie administracji ze społeczeństwem, Warszawa 1985. 
jednostek samorządu terytorialnego z innymi podmiotami publicznymi oraz z podmiotami niepublicznymi.

Dobór odpowiednich form, a także dobór określonych podmiotów współdziałania jest determinowany różnorodnymi przesłankami. Przykładowo potrzeba uspołecznienia procesu wykonywania zadań publicznych przesądza o sięganiu po takie formy współdziałania, których podmiotami, obok samorządu terytorialnego, będą też niepubliczne podmioty administrujące (m.in. organizacje pożytku publicznego) $)^{4}$. Z kolei dążenie do zapewnienia efektywnego ekonomicznie świadczenia usług publicznych skłania jednostki samorządu terytorialnego do sięgania np. po partnerstwo publiczno-prywatne, szczególnie ważne w przypadku realizacji bez angażowania środków publicznych kosztownych inwestycji, takich jak np. budowa w dużym mieście przystanków komunikacji miejskiej, których powierzchnia reklamowa jest następnie przez podmiot prywatny realizujący inwestycję wykorzystywana w ściśle określonym terminie (w założeniu do czasu osiągnięcia zwrotu poniesionych kosztów i zakładanego zysku). Natomiast w przypadku szczególnej kapitałochłonności niektórych zadań publicznych dla zwiększenia potencjału organizatorskiego i ekonomicznego niezbędnego dla ich należytego wykonywania poszczególne jednostki samorządu terytorialnego sięgają po takie formy, które gwarantują im wsparcie innych jednostek samorządu tery torialnego dysponujących odpowiednim potencjałem. Wskazując przesłanki podjęcia współdziałania, należy też wyraźnie zaznaczyć, że jego poszczególni uczestnicy wcale nie muszą mieć tożsamej motywacji skłaniającej ich do współdziałania. Mogą się kierować zgoła odmiennymi motywami. Niezależnie jednak od tego, czy motywacja poszczególnych jednostek samorządu terytorialnego zainteresowanych współdziałaniem jest tożsama, zbieżna czy też różna, czy jednostki te cechuje podobny czy też różny potencjał ekonomiczny, organizacyjny, niewątpliwe jest, że aby doszło do decyzji o współdziałaniu konkretnych jednostek, musi je łączyć wspólnota interesów.

${ }^{4}$ Por. bliżej M. Stahl, Niepubliczne podmioty administrujące [w:] System Prawa Administracyjnego, t. 6, Podmioty administrujace, red. R. Hauser, Z. Niewiadomski, A. Wróbel, Warszawa 2011, s. 529 i n. 
Patrząc na współdziałanie samorządu terytorialnego z perspektywy podmiotów współdziałających, wyodrębniamy jego dwie zasadnicze postaci:

1) współdziałanie w samorządzie terytorialnym oraz

2) współdziałanie $z$ udziałem samorządu terytorialnego.

Współdziałanie w samorządzie terytorialnym charakteryzuje się tym, że jego uczestnikami są wyłącznie jednostki tego samorządu. Natomiast współdziałanie z udziałem jednostek samorządu terytorialnego łączy jednostki tego samorządu oraz podmioty spoza systemu samorządu terytorialnego, którymi mogą być zarówno podmioty publiczne (przede wszystkim organy administracji rządowej), jak i podmioty niepubliczne (np. organizacje pozarządowe). Należy tu jedynie sygnalizacyjnie wspomnieć, że współdziałanie z udziałem samorządu terytorialnego może być inspirowane zarówno przez te jednostki, chcące np. realizować zadania z zakresu administracji rządowej, jak też może być inspirowane przez podmioty spoza systemu samorządu terytorialnego, które są zainteresowane realizacją zadań jednostek samorządowych.

Warto też podkreślić, że w niektórych sytuacjach przedmiot działania, np. wspieranie rozwoju regionalnego, determinuje nie tylko formę współdziałania, jaką jest obecnie kontrakt terytorialny ${ }^{5}$, ale też wskazuje kategorie uczestników współdziałania, którymi są województwo samorządowe i administracja rządowa, a w dalszej kolejności - inni partnerzy samorządowi, gospodarczy i społeczni ${ }^{6}$.

Nie ulega wątpliwości, że charakter zadań publicznych przesądza o doborze prawnych form ich realizacji. A zatem wspólne wykonywanie zadań publicznych, tak samo jak ich realizacja „w pojedynkę”,

${ }^{5}$ Do wejścia w życie ustawy z 24.01.2014 r. o zmianie ustawy o zasadach prowadzenia polityki rozwoju oraz niektórych innych ustaw (Dz.U. poz. 379) był to kontrakt wojewódzki.

${ }^{6}$ B. Dolnicki, R. Cybulska, Nowe dwustronne formy działania administracji publicznej - zagadnienia wybrane [w:] Koncepcja systemu prawa administracyjnego. Zjazd Katedr Prawa Administracyjnego i Postępowania Administracyjnego, Zakopane 24-27 września 2006 r., red. J. Zimmermann, Warszawa 2007, s. 471. 
może być prowadzone w formie działań organizatorskich, ale może być również - i wciąż w szerokim zakresie jest - prowadzone w formach władczych, przyjmujących postać aktów stanowienia i aktów stosowania prawa. Warto w tym miejscu wskazać, że współdziałanie organów administracji przy wydawaniu decyzji administracyjnych jest instytucją trwale zakorzenioną w prawie administracyjnym ${ }^{7}$, na którą reaktywowanie w Polsce samorządu terytorialnego nie miało zasadniczego wpływu, oczywiście poza tym, że do współdziałania przy wydawaniu decyzji administracyjnych zostały włączone również organy jednostek samorządu terytorialnego występujące w różnych rolach: zarówno organu decyzyjnego, jak i organu zajmującego stanowisko w różnych formach (np. zgody, opinii) ${ }^{8}$.

Popularność współdziałania znajduje odzwierciedlenie w szerokim zainteresowaniu tą problematyką doktryny ${ }^{9}$, w której dorobku spotkać

${ }^{7}$ Jest to przede wszystkim instytucja prawa materialnego, przewidziana przykładowo w art. 18 ust. 3a, 4 ustawy z 26.10.1982 r. o wychowaniu w trzeźwości i przeciwdziałaniu alkoholizmowi (Dz.U. z 2016 r. poz. 487 ze zm.), ale też prawa procesowego - ujęta w art. 106 k.p.a., który reguluje zasady i tryb współdziałania organów administracji publicznej przy wydawaniu decyzji administracyjnych.

${ }^{8}$ Por. J. Borkowski, Uprawnienia organu samorządu terytorialnego współdziałajacego przy wydawaniu decyzji, „Jurysta” 1995/1; B. Jaworska-Dębska, Współdziałanie organów samorządu terytorialnego przy wydawaniu decyzji administracyjnych [w:] Prawo. Administracja. Obywatele. Profesorowi Eugeniuszowi Smoktunowiczowi, red. A. Jamróz, Białystok 1997; P. Kledzik, Współdziałanie jednostek samorządu terytorialnego w zakresie stanowienia i stosowania prawa [w:] Formy współdziałania jednostek samorządu terytorialnego, red. B. Dolnicki, Warszawa 2012, s. 428 i n.; B. Adamiak, Uwagi o samodzielności organu samorządu terytorialnego $w$ kształtowaniu treści rozstrzygnięcia sprawy indywidualnej decyzja administracyjna [w:] Aktualne problemy funkcjonowania samorządu terytorialnego, red. E. Ura, E. Feret, S. Pieprzny, Sandomierz-Rzeszów 2017. Z literatury wcześniejszej dotyczącej współdziałania przy wydawaniu decyzji administracyjnych por. np. J. Borkowski, Współdziałanie organów administracji państwowej przy wydawaniu indywidualnych decyzji administracyjnych, "Zeszyty Naukowe Uniwersytetu Łódzkiego" 1963/31; J. Świątkiewicz, Z problematyki współdecyzji organów w prawie administracyjnym, PiP 1964/5-6.

9 Por. m.in. S. Biernat, Działania wspólne w administracji państwowej, WrocławWarszawa-Kraków-Gdańsk 1979; Z. Leoński, Formy współdziałania w samorzadzie terytorialnym, ST 1995/4; M. Ofiarska, Formy publicznoprawne współdziałania jednostek samorządu terytorialnego, Warszawa 2008; Z. Niewiadomski, Współdziałanie komunalne [w:] System..., red. R. Hauser, Z. Niewiadomski, A. Wróbel, t. 6, Podmioty...; P. Łazutka, 25 lat współdziałania jednostek samorządu terytorialnego $w$ Polsce $w$ formie zwiazku celowego. Analiza obecnego stanu prawnego i postulaty de lege ferenda [w:] 
można wiele klasyfikacji form współdziałania. Dla dalszych rozważań przydatne będzie wyodrębnienie prywatnoprawnych i publicznoprawnych form współdziałania jednostek samorządu terytorialnego. W niniejszym opracowaniu problematyka samodzielności współdziałających jednostek samorządu terytorialnego odnoszona będzie jedynie do związków komunalnych jako podstawowej publicznoprawnej instytucjonalnej formy współdziałania lokalnych jednostek samorządu terytorialnego (związków międzygminnych, związków powiatowo-gminnych oraz związków powiatów) ${ }^{10}$ oraz do związku metropolitalnego ${ }^{11}$. Poza rozważaniami pozostaną więc inne - publiczne oraz niepubliczne, zarówno instytucjonalne, jak i funkcjonalne - formy współdziałania jednostek samorządu terytorialnego, a także formy współdziałania $\mathrm{z}$ udziałem tych jednostek.

2. Ocena samodzielności jednostek samorządu terytorialnego współdziałających w wybranych formach wymaga w tym miejscu, choćby wielce skrótowego ${ }^{12}$, spojrzenia na tę samodzielność. Przede wszystkim należy wskazać, że samodzielność jednostek samorządu terytorialnego jest istotą samorządu, jest zasadniczym elementem definiującym samorząd terytorialny, zawartym w podstawowych aktach ustrojowych, w EKSL, Konstytucji RP oraz w samorządowych ustawach ustrojowych. Rzecz jasna samodzielność jednostek samorządu terytorialnego, choć w nie tak bezpośredni sposób, jest też normowana w wielu innych aktach ${ }^{13}$.

Prawne problemy samorządu terytorialnego z perspektywy 25-lecia jego funkcjonowania, red. B. Jaworska-Dębska, R. Budzisz, Warszawa 2016.

${ }^{10}$ Nie ma wszakże ustawowych podstaw dla tworzenia związków przez jednostki samorządu regionalnego.

${ }^{11}$ Ustawa z 9.03.2017 r. o związku metropolitalnym w województwie śląskim (Dz.U. poz. 730).

${ }_{12}$ W pełni podzielić bowiem trzeba wyrażany przez M. Mączyńskiego pogląd, że „samodzielność jednostek samorządu terytorialnego może być pojmowana bardzo szeroko tj. zarówno jako podstawowa cecha samorządu, jak i jako zasada prawna, wartość aksjologiczna, cel i skutek decentralizacji oraz jako władztwo do samodzielnego podejmowania decyzji dotyczących własnego rozwoju”. M. Mączyński, Samodzielność a samorządność [w:] Nadzór nad samorządem a granice jego samodzielności, red. M. Stec, M. Mączyński, Warszawa 2011, s. 28.

13 Przykładowo w ustawie z 15.09.2000 r. o referendum lokalnym (Dz.U. z 2016 r. poz. 400 ze zm.). 
Samodzielność prawna jednostek samorządu terytorialnego zasadza się na swobodzie ich działania w granicach prawa ${ }^{14}$. W świetle EKSL oznacza to pełną swobodę społeczności lokalnych działania w każdej sprawie, która nie jest wyłączona $\mathrm{z}$ ich kompetencji lub nie wchodzi w zakres kompetencji innych organów władzy. Artykuł 163 Konstytucji RP formułuje generalne domniemanie zadań samorządu terytorialnego w zakresie zadań publicznych. Samorząd terytorialny wykonuje zadania publiczne niezastrzeżone przez Konstytucję lub ustawy dla organów innych władz publicznych. Samodzielność ta oznacza w szczególności posiadanie przez jednostki samorządu terytorialnego określonego zakresu zadań własnych służących zaspokajaniu potrzeb mieszkańców, wykonywanie przez nie zadań publicznych ${ }^{15}$ we własnym imieniu i na własną odpowiedzialność. Samodzielności w tym zakresie służą takie atrybuty jednostek samorządu terytorialnego, jak osobowość prywatnoprawna, umożliwiająca im bycie podmiotem prawa własności i innych praw majątkowych, oraz podmiotowość publicznoprawna ${ }^{16}$, oznaczająca przede wszystkim prawo dysponowania władztwem państwowym.

Publicznoprawne upodmiotowienie jednostki samorządu terytorialnego oznacza m.in. jej prawo (poprzez jej organy stanowiące) do określania, w granicach ustaw, jej wewnętrznego ustroju w uchwalanych statutach, co w doktrynie określane jest mianem ustrojowej samodzielności jednostek samorządu terytorialnego ${ }^{17}$.

${ }^{14}$ Zgodnie z art. 3 ust. 1 EKSL: „Samorząd lokalny oznacza prawo i zdolność społeczności lokalnych, w granicach określonych prawem, do kierowania i zarządzania zasadniczą częścią spraw publicznych na ich własną odpowiedzialność i w interesie ich mieszkańców".

${ }^{15}$ Zgodnie $\mathrm{z}$ art. 16 ust. 2 Konstytucji RP jest to istotna część zadań publicznych.

${ }^{16}$ Oczywiście, jak trafnie zauważa A. Wiktorowska - A. Wiktorowska, Prawne determinanty samodzielności gminy. Zagadnienia administracyjnoprawne, Warszawa 2002, s. 82 - określenie „osobowość prawa publicznego” nie występuje w języku prawnym, współcześnie można się nim posługiwać jedynie w języku prawniczym.

17 Por. m.in. A. Wiktorowska, Prawne..., s. 83 i n.; I. Skrzydło-Niżnik, Model ustroju samorzq̨du terytorialnego w Polsce na tle zagadnień ustrojowego prawa administracyjnego, Kraków 2007, s. 315. Bliższe ujęcie tej problematyki por. m.in. B. Adamiak, Statut gminy, ST 1993/7-8; J. Korczak, Statuty jednostek samorządu terytorialnego, ST 2000/5. 
W sferze finansowej samodzielność jednostek samorządu terytorialnego wyraża się przede wszystkim w konstytucyjnej gwarancji posiadania przez nie udziału $w$ dochodach publicznych odpowiednio do przypadających im zadań. Nadto ustrojodawca określił też samodzielność podatkową, wyrażającą się w prawie jednostek samorządu terytorialnego do ustalania wysokości podatków i opłat lokalnych w zakresie określonym w ustawie.

Samodzielność jednostek samorządu terytorialnego, niezależnie od wskazania jej atrybutów in abstracto, dla bliższej charakterystyki wymaga też ustalenia otoczenia, w którym funkcjonują samodzielne jednostki samorządu terytorialnego. Dlatego też należy wyraźnie zaznaczyć, że samodzielność jednostek samorządu terytorialnego oznacza nie tylko wolność od ingerencji w ich sprawy ze strony państwa ${ }^{18}$, ale też ze strony innych jednostek samorządu ${ }^{19}$. Nie ulega wątpliwości, że działania samorządu terytorialnego nie są wyjęte spod państwowego porządku prawnego i muszą się mieścić w jego ramach. Dlatego też samodzielności w tym pierwszym wymiarze służy ograniczenie ingerencji państwa w ramach nadzoru nad samorządem jedynie do kryterium legalności. Nadzór prawny (legalny) gwarantuje bowiem działanie samorządu w ramach państwowego porządku prawnego. Ograniczenie nadzoru nad samorządem terytorialnym jedynie do

${ }^{18}$ Na marginesie warto zaznaczyć, że uwagę przedstawicieli doktryny w znacznym stopniu skupia problem samodzielności samorządu terytorialnego wobec administracji rządowej (por. np. M. Stahl, Samorząd terytorialny a państwo, „Studia Prawno-Ekonomiczne" 1992/46; J.P. Tarno [w:] Samorzad terytorialny w Polsce, red. J.P. Tarno, Warszawa 2002, s. 25). Jest to w pełni zrozumiałe i oczywiste, jeśli zważyć, że reaktywowanie samorządu terytorialnego w Polsce w 1990 r. oznaczało wprowadzenie do systemu władzy publicznej nowego elementu, czyli jednostki samorządu terytorialnego jako odrębnego wobec państwa podmiotu władzy publicznej, oznaczało więc nową rzeczywistość w strukturze władzy lokalnej. W tych warunkach nie dziwi więc rozpatrywanie samodzielności jednostki samorządu przede wszystkim wobec drugiego segmentu władzy publicznej, czyli wobec administracji rządowej.

${ }_{19} \mathrm{~W}$ doktrynie wskazuje się na potrzebę rozpatrywania samodzielności jednostek samorządu terytorialnego jako samodzielności wobec organów administracji rządowej oraz jako samodzielności jednostek samorządu terytorialnego względem siebie. Por. E. Bojanowski, Samodzielność wspólnot samorządowych wewnątrz systemu samorządu terytorialnego [w:] Granice samodzielności wspólnot samorządowych, red. E. Ura, Rzeszów 2005, s. 28. 
nadzoru legalnego uniemożliwia ingerencję w ramach nadzoru sprawowanego przy użyciu kryteriów ocennych, jak np. celowość, rzetelność, gospodarność, stwarzających niebezpieczeństwo ograniczania sfery samodzielności jednostki samorządu. Samodzielność jednostek samorządu terytorialnego oznacza również wolność od ingerencji w ich sprawy ze strony innych jednostek samorządu, od których są one niezależne, co zostało expressis verbis wyrażone w art. 4 ust. 2 u.s.w., zgodnie z którym organy samorządu województwa nie stanowią wobec powiatu i gminy organów nadzoru lub kontroli oraz nie są organami wyższego stopnia w postępowaniu administracyjnym.

3. Niniejsze opracowanie ma na celu poszukiwanie odpowiedzi na pytanie, czy współdziałanie w formie związku komunalnego oraz związku metropolitalnego w województwie śląskim odciska się w jakimś stopniu na zakresie samodzielności jednostki samorządu realizującej swoje zadania w tych formach współdziałania czy też nie. Innymi słowy - czy zakres samodzielności jednostki współdziałającej w tych formach jest taki sam jak jednostki samorządu terytorialnego działającej „w pojedynkę” czy też się zmienia, a jeśli tak, to w jakim kierunku, rozszerza się, czy też raczej ulega zawężeniu. W tym celu zostanie ukazanych kilka aspektów samodzielności jednostek samorządu lokalnego współdziałających we wskazanych formach. Chodzi o samodzielność tych jednostek: w zakresie znaczenia ich woli w sprawie udziału we współdziałaniu (w tym podjęcia oraz rezygnacji); w zakresie ustalenia przedmiotu współdziałania; w zakresie wyboru partnerów współdziałania; w zakresie wyboru formy współdziałania; w przedmiocie ustalenia ustrojowych podstaw formy współdziałania, jaką jest związek komunalny oraz związek metropolitalny, a także w przedmiocie zachowania przez współdziałające jednostki własnej, odrębnej od związku podmiotowości prawnej.

3.1. Zgodnie $\mathrm{z}$ art. 10 ust. 1 EKSL społeczności lokalne mają prawo współpracy z innymi społecznościami lokalnymi w celu realizacji zadań, które stanowią przedmiot ich wspólnego zainteresowania. Prawo to znajduje odzwierciedlenie w samorządowych ustawach ustrojowych, przewidujących prawo gmin i powiatów współdziałania m.in. w formie związków komunalnych. Nie ulega wątpliwości, że dobrowolność 
współdziałania jest zasadą przewidzianą w samorządowym prawie ustrojowym ${ }^{20}$. Jak już wskazano, dobrowolność współdziałania w formie związku komunalnego expressis verbis ustawowo odnoszona jest do tworzenia związków międzygminnych, związków powiatów oraz związków powiatowo-gminnych ${ }^{21}$. Tak ustawowo określonej dobrowolności nie można jednak rozumieć literalnie i ograniczać jedynie do tworzenia związków, z jednoczesnym wyłączeniem dobrowolności przystępowania do już istniejących związków, czy też z wyłączeniem prawa do wystąpienia z nich. Naruszałoby to w oczywisty sposób reguły logiki. Skoro bowiem gminy i powiaty mają swobodę w zakresie tworzenia tej formy współdziałania, jaką jest związek, to należy też uznać, że mogą one przystąpić do już istniejącego związku, utworzonego przez inne jednostki samorządu terytorialnego. Gminy i powiaty mogą też ze związku wystąpić. Zresztą art. 65 ust. 2 u.s.p., wskazujący na uchwały zainteresowanych powiatów o utworzeniu związku powiatów, ale też o przystąpieniu do związku lub o wystąpieniu ze związku, potwierdza słuszność powyższego rozumowania. Powyższy pogląd znajduje też wyraz w doktrynie ${ }^{22}$, koresponduje również ze stanowiskiem orzecznictwa uznającego, że zasada dobrowolności oznacza, że gmina ma prawo suwerennego decydowania zarówno o utworzeniu związku, przystąpieniu do niego, jak i wystąpieniu $\mathrm{z}$ niego ${ }^{23}$. W odniesieniu do związku międzygminnego problem ten w pewnym stopniu został też dostrzeżony przez ustawodawcę, który w jednej z ostatnich nowelizacji u.s.g., regulując procedurę tworzenia związku międzygminnego, rozszerzył ją też na przystąpienie do związku. Prawo wystąpienia gminy ze związku nie zostało jednak $\mathrm{w}$ u.s.g. expressis verbis sformułowane.

Od wskazanej wyżej dobrowolności współdziałania w formie związków, na gruncie u.s.g. i u.s.p. sformułowanej expressis verbis jedynie w odniesieniu do gmin, dopuszczony jest wyjątek przewidujący, że

${ }^{20}$ Jak trafnie podnosi M. Ofiarska, „o ile [...] ustawodawca nie stanowi inaczej, jednostkom samorządu terytorialnego nie można zakazać współdziałania, nie można także ich zobowiązać do współdziałania wbrew ich woli”. M. Ofiarska, Formy..., s. 339.

${ }^{21}$ Art. 64 u.s.g. oraz art. 65 ust. 1 u.s.p. i art. 72a u.s.p.

22 B. Dolnicki, Samorzad terytorialny, Warszawa 2016, s. 331.

${ }^{23}$ Por. wyrok WSA w Gliwicach z 4.03.2008 r., IV SA/Gl 49/08, LEX nr 466375. 
obowiązek utworzenia związku może być nałożony tylko w drodze ustawy, która określa zadania związku i tryb zatwierdzania jego statutu $^{24}$. Oznacza to, że obligatoryjny związek międzygminny może być utworzony z mocy ustawy, ale też obowiązek utworzenia związku może być nałożony na gminy w drodze ustawy ${ }^{25}$. W pełni podzielić też należy wyrażany w doktrynie pogląd, że brak w u.s.p. analogicznego unormowania nie stanowi przeszkody dla ustawowego nałożenia na powiaty obowiązku utworzenia związku, gdyż ustawodawca nie potrzebuje upoważnienia ustawowego do nałożenia takiego obowiązku inną ustawą ${ }^{26}$.

A zatem dobrowolność współdziałania jednostek samorządu lokalnego i ich samodzielność w tym zakresie wyraża się w konstytutywnym znaczeniu ich woli dla określenia sposobu wykonywania należących do zakresu ich działania zadań publicznych, „w pojedynkę" lub we współdziałaniu. Podejmując decyzję o wykonywaniu zadań „w pojedynkę", jednostki samorządu lokalnego będą też wyrażały swą wolę w przedmiocie odmowy zgody na propozycję współdziałania czy rezygnacji ze współdziałania. $W$ przypadku zaś podjęcia decyzji o współdziałaniu dobrowolność i samodzielność jednostek samorządu lokalnego wyraża się także w konstytutywnym znaczeniu ich woli nie tylko w przedmiocie inicjowania współdziałania, ale też wyrażenia zgody na składaną przez inną jednostkę samorządu propozycję współdziałania, a także dla wskazania innych uczestników współdziałania.

Natomiast niewątpliwie gminy nie posiadają samodzielności w kwestii uczestnictwa w związku metropolitalnym w województwie śląskim ${ }^{27}$. Członkostwo w nim miasta na prawach powiatu Katowice jest expressis

24 Art. 64 ust. 4 u.s.g.

${ }^{25}$ K. Bandarzewski, Art. 64 [w:] Ustawa o samorzadzie gminnym. Komentarz, red. P. Chmielnicki, Warszawa 2013, s. 780.

${ }^{26}$ M. Grążawski, M. Małecka-Łyszczek, Związek jako forma współdziałania jednostek samorzadu terytorialnego [w:] Jednostka, państwo, administracja - nowy wymiar. Międzynarodowa konferencja naukowa Olszanica, 23-26 maja 2004 r., red. E. Ura, Rzeszów 2004, s. 189-190.

${ }^{27}$ Ustawa z 9.03.2017 r. o związku metropolitalnym w województwie śląskim (Dz.U. poz. 730). 
verbis ustawowo określone, ma więc charakter obligatoryjny, zaś katalog gmin-uczestników związku metropolitalnego jest pierwotnie określony we wniosku rady miasta Katowice o utworzenie tego związku. W żadnym wymiarze nie posiadają tej samodzielności gminy włączone do tego związku wbrew swojej woli, ponieważ w świetle ustawowo określonej procedury jego tworzenia możliwa jest sytuacja, że Rada Ministrów, tworząc w drodze rozporządzenia w województwie śląskim związek metropolitalny, może wśród gmin wchodzących w jego skład wskazać również gminy, które nie wyraziły w tej sprawie pozytywnej opinii, byleby liczba tych gmin nie przekraczała $30 \%$ wszystkich gmin, które zgodnie z wnioskiem miały wejść w skład związku metropolitalnego i które były objęte procedurą opiniodawczą.

3.2. Poza znaczeniem woli jednostki samorządu lokalnego w zakresie podjęcia współdziałania, zasadniczym aspektem, w którym wyraża się samodzielność jednostki samorządu lokalnego, jest przede wszystkim jej prawo ustalenia przedmiotu współdziałania, czyli określenia rodzaju zadań publicznych przeznaczonych do wykonywania we współdziałaniu oraz ocena przez jednostkę samorządu jej własnych możliwości i potrzeb w tym zakresie.

Współdziałające w formie związku komunalnego jednostki samorządu lokalnego samodzielnie decydują o przedmiocie współdziałania w tej formie.

Zasadniczo odmiennie kształtuje się kwestia samodzielności gminy-uczestnika związku metropolitalnego w zakresie ustalenia przedmiotu współdziałania, gdyż zakres zadań realizowanych w tej formie współdziałania jest ustawowo określony w postaci enumeratywnego wyliczenia, obejmującego: kształtowanie ładu przestrzennego; rozwój społeczny i gospodarczy obszaru związku metropolitalnego; planowanie, koordynację, integrację oraz rozwój publicznego transportu zbiorowego, w tym transportu drogowego, kolejowego oraz innego transportu szynowego, a także zrównoważonej mobilności miejskiej; metropolitalnych przewozów pasażerskich; współdziałania w ustalaniu przebiegu dróg krajowych i wojewódzkich na obszarze związku metropolitalnego; promocji związku metropolitalnego i jego obszaru. 
Ten sposób określenia zadań związku metropolitalnego nie pozostawia jednostce samorządu terytorialnego-uczestnikowi tego związku żadnej sfery samodzielności w kształtowaniu przedmiotu współdzialania w tej formie.

3.3. In abstracto jednostki samorządu lokalnego współdziałające $\mathrm{w}$ formie związku komunalnego niewątpliwie dysponują samodzielnością w doborze partnera współdziałania, jednakże pamiętać trzeba, że in concreto ich swoboda w tym zakresie nie jest absolutna, przede wszystkim jest ona determinowana takimi czynnikami, jak charakter i zakres zadań publicznych, które mają być realizowane we współdziałaniu. Na dobór partnerów współdziałania (w sensie pozytywnym lub negatywnym) rzutować też będą cechy sąsiednich jednostek samorządu lokalnego.

Gdy zaś chodzi o zakres samodzielności jednostek samorządu terytorialnego w doborze partnera współdziałania w formie związku metropolitalnego w województwie śląskim, to należy zaznaczyć, że miasto na prawach powiatu Katowice ma pewien, choć ograniczony postanowieniami ustawy, wpływ na dobór innych gmin województwa śląskiego jako członków związku metropolitalnego w województwie śląskim. Wskazuje bowiem we wniosku do Rady Ministrów o utworzenie tego związku inne gminy tego województwa charakteryzujące się istnieniem silnych powiązań funkcjonalnych oraz zaawansowaniem procesów urbanizacyjnych, położone na obszarze spójnym pod względem przestrzennym, który zamieszkuje co najmniej 2000000 mieszkańców. Wprawdzie to rada miasta Katowice wskazuje gminy, które mają wchodzić w skład tego związku, ale wydanie przez Radę Ministrów rozporządzenia o utworzeniu w województwie śląskim związku metropolitalnego we wskazanym składzie wymaga pozytywnej opinii rad co najmniej 70\% gmin, które mają wejść do tego związku. Powyższe rozwiązanie umożliwia zatem powstanie sytuacji, w której brak pozytywnej opinii rad tej większości gmin sprawi, że Rada Ministrów nie będzie mogła utworzyć związku metropolitalnego we wskazanym przez radę miasta Katowice składzie gmin i że nie wejdą one w skład tego związku. Nie wejdą w skład związku także te $\mathrm{z}$ nich, które wyraziły pozytywną opinię w tym przedmiocie. 
3.4. Zagadnienie zakresu samodzielności jednostki samorządu lokalnego w przedmiocie wyboru związku komunalnego jako formy współdziałania sprowadzić można do konstatacji, że zasadniczo wybór odpowiedniej formy spośród wielu form współdziałania należy do zainteresowanej współdziałaniem jednostki samorządu terytorialnego. Oczywiście zaznaczenia wymaga, że wybór ten mieścić się musi w granicach obowiązującego prawa, a wybrana forma musi być adekwatna do przyjętych zadań ${ }^{28}$. Co do zasady więc wprawdzie rodzaj zadań publicznych, które mają być realizowane w ramach współdziałania, nie przesądza doboru odpowiedniej formy współdziałania, to jednak w znacznym stopniu może ten wybór determinować. Dlatego też słusznie uznaje się, że „swoboda wyboru prawnej formy współdziałania jest ograniczona ustawowym celem danej formy ${ }^{29}$. Myśl ta ma też pełne zastosowanie do związku metropolitalnego w województwie śląskim, gdyż cel tej formy współdziałania, niewyrażony wprawdzie wprost w ustawie, ale dekodowany jako realizacja zadań publicznych o wymiarze metropolitalnym w tym województwie, w obecnym stanie prawnym może być zrealizowany wyłącznie w ramach związku metropolitalnego w województwie śląskim.

3.5. Samodzielność współdziałających jednostek samorządu lokalnego wyraża się też w zakresie ich udziału w ustalaniu ustrojowych podstaw wybranej formy współdziałania, związku międzygminnego, związku powiatów, związku powiatowo-gminnego oraz związku metropolitalnego w województwie śląskim. Należy zaznaczyć, że udział ten jest znacznie zróżnicowany, co w dalszej kolejności przekłada się - rzecz jasna - na zakres samodzielności tych jednostek samorządu w budowaniu ustrojowych podstaw związków.

Gdy chodzi o rolę gmin i powiatów tworzących związek komunalny (międzygminny, powiatów, powiatowo-gminny) w ustaleniu statutu związku, to należy podkreślić, że mają one prawo do kształtowania treści statutu związku, jednakże ich udział w tej sprawie jest ograniczony obowiązkiem uzgodnienia projektu statutu z wojewodą.

\footnotetext{
${ }^{28}$ M. Ofiarska, Formy..., s. 340.

${ }^{29}$ M. Ofiarska, Formy..., s. 340.
} 
Gdy zaś chodzi o rolę gmin-przyszłych uczestników związku metropolitalnego $\mathrm{w}$ województwie śląskim w kształtowaniu treści jego statutu, to wobec okoliczności, że ich wola nie ma przesądzającego wpływu na ich członkostwo w tej formie współdziałania i nie uczestniczą one w opracowywaniu projektu statutu związku metropolitalnego w żadnej formie, należy uznać, że nie mają one żadnego, nawet ograniczonego, wpływu na kształtowanie treści statutu tego związku. Opracowanie projektu jego statutu należy bowiem do zadań pełnomocnika do spraw utworzenia związku metropolitalnego, którym z mocy ustawy jest prezydent miasta Katowice. Zatem nawet obligatoryjny uczestnik tego związku, jakim jest miasto na prawach powiatu Katowice, nie uczestniczy w kształtowaniu treści statutu związku metropolitalnego województwa śląskiego. Opracowując projekt jego statutu, prezydent miasta Katowice nie reprezentuje tej jednostki samorządu, występuje bowiem jako ustawowo wskazany pełnomocnik do spraw utworzenia związku metropolitalnego. Dodatkowo projekt statutu związku metropolitalnego województwa śląskiego i jego zmian podlega uzgodnieniu z Prezesem Rady Ministrów na wniosek ministra właściwego do spraw administracji publicznej.

3.6. Uczestnictwo jednostek samorządu lokalnego w związku komunalnym nie pozbawia ich podmiotowości i samodzielności, gdyż przekazując na rzecz związku komunalnego część należących do ich właściwości zadań i kompetencji, nie wyzbywają się w związku z tym swej podmiotowości prawnej. Są one nadal odrębnymi podmiotami prawa publicznego, tak jak inne jednostki samorządu niebędące członkami związku komunalnego ${ }^{30}$. Wprawdzie stanowisko powyższe zostało sformułowane w odniesieniu do gmin-uczestników związku, to jednak porównywalność pozycji prawnej gmin i powiatów jako uczestników związków komunalnych stwarza podstawy do uznania, że stanowisko to zachowuje swą aktualność również w odniesieniu do powiatów-uczestników związku. Warto tu też zaznaczyć, że podmio-

${ }^{30}$ B. Jaworska-Dębska, Glosa do wyroku NSA z 12.07.2006 r. (II OSK 571/06, niepubl.), „Przegląd Prawa Publicznego” 2007/6, s. 103. Podobnie W. Kisiel, Sądowa kontrola i ochrona samorzadu terytorialnego [w:] Prawo samorzadu terytorialnego $w$ Polsce, red. W. Kisiel, Warszawa 2006, s. 379-380. 
towość jednostek samorządu lokalnego-uczestników związku komunalnego została w ramach nowelizacji u.s.g. oraz u.s.p. wyraźnie zaakcentowana i wzmocniona, stworzono bowiem podstawy prawne do wniesienia przez radę gminy/radę powiatu sprzeciwu w stosunku do uchwały zgromadzenia związku zmieniającej statut związku ${ }^{31}$.

Natomiast wskazane wyżej odrębności związku metropolitalnego województwa śląskiego od związku komunalnego, w tym przede wszystkim okoliczność, że uczestnicy tego związku nie mają przesądzającego wpływu na swe uczestnictwo w związku, a także okoliczność, że zadania tego związku nie powstają w wyniku przekazania ich na rzecz związku przez gminy-uczestników, ale są one związkowi ustawowo przypisane, wymagają osobnego podejścia do zagadnienia wpływu uczestnictwa w związku metropolitalnym na zachowanie własnej podmiotowości pozwalającej na prezentowanie i ochronę własnego interesu prawnego. Wymaga to przede wszystkim odpowiedzi na pytanie, czym są zadania tego związku. Wydaje się, że ich natura prawna nie pozostawia wątpliwości, iż jest to odrębna kategoria zadań metropolitalnych, na które składają się zarówno zadania lokalne, jak i zadania regionalne ${ }^{32}$. A specyfika tych zadań, wyrażająca się przede wszystkim $w$ istnieniu powiązań funkcjonalnych między uczestnikami związku metropolitalnego, sprawia, że w rezultacie w tej sferze zaciera się między nimi ich odrębność. W sferze zadań związku metropolitalnego nie sposób więc przyjąć, że interes prawny jednej gminy-uczestnika związku może być przeciwstawiany interesowi całej metropolii, co jednak przekłada się na ograniczenie jej samodzielności w tym zakresie. Jedynie gdy chodzi o kwestie organizacyjne dotyczące władz związku metropolitalnego, należy uznać, że jednostki samorządu-uczestnicy tego związku w pełni zachowują swoją samodzielność, pozwalającą na obronę swego interesu prawnego przed sądem.

31 Ustawa z 25.06.2015 r. o zmianie ustawy o samorządzie gminnym oraz niektórych innych ustaw (Dz.U. poz. 1045).

${ }^{32}$ Jak się słusznie wskazuje w doktrynie: „Zadania metropolitalne łączą w sobie [...] zarówno elementy typowe dla zadań lokalnych, jak i regionalnych”. Por. B. Dolnicki, R. Marchaj, Związek metropolitalny w województwie śląskim, ST 2017/7-8, s. 12. 
4. Nie ulega wątpliwości, że współdziałanie przynosi korzyści w sferze realizacji zadań publicznych. Dotyczy to również współdziałania jednostek samorządu, których zasadniczym atrybutem jest samodzielność. Niniejsze opracowanie służy poszukiwaniu odpowiedzi na pytanie, czy te niewątpliwe korzyści współdziałania jednostek samorządu nie są pomniejszone o ewentualne straty wyrażające się w ograniczeniu sfery samodzielności współdziałających jednostek.

Przeprowadzona analiza pozwala na oczekiwaną konstatację, że zasadniczo współdziałanie jednostek samorządu lokalnego w formie związku komunalnego nie ogranicza sfery samodzielności współdziałających jednostek. Gdyby było inaczej, to instytucja współdziałania stanowiłaby zagrożenie dla samorządu, a tym samym - dla decentralizacji, a tak przecież nie jest.

Jednakże, jak już wyżej wskazywano, samodzielność statutowa związku komunalnego (a więc i możliwość wpływania na treść statutu tworzących związek jednostek samorządu lokalnego) jest ograniczona przez obowiązek uzgodnienia projektu statutu związku z wojewodą. Uzgodnienie to oznacza uzyskanie zgody wojewody na uchwalenie statutu związku zgodnie z przedłożonym projektem. Warto tu jednak zaznaczyć, że ograniczenie tej sfery samodzielności nie jest charakterystyczne jedynie dla jednostek - przyszłych uczestników związku, biorąc bowiem pod uwagę tylko jednostki samorządu lokalnego, podobne rozwiązanie jest też przewidziane w odniesieniu do statutów dużych gmin. Większe gminy (liczące powyżej 300000 mieszkańców) oraz związki komunalne nie dysponują więc pełną samodzielnością decydowania o swoim ustroju. Uchwalenie statutu gminy liczącej powyżej 300000 mieszkańców wymaga bowiem uzgodnienia z Prezesem Rady Ministrów ${ }^{33}$. Podzielić w tym miejscu wypada zgłaszaną w doktrynie wątpliwość co do celowości wprowadzenia powyż-

${ }^{33} \mathrm{Na}$ marginesie, warto $\mathrm{w}$ tym miejscu wskazać na brak jednolitości rozwiązań $\mathrm{w}$ tym przedmiocie zawartych $\mathrm{w}$ samorządowych ustawach ustrojowych, ponieważ samodzielność powiatu w zakresie ustalenia jego ustrojowych podstaw nie została w podobny sposób ograniczona poprzez konieczność jego uprzedniego uzgadniania z Prezesem Rady Ministrów. 
szego rozwiązania ${ }^{34}$. Słusznie się podnosi, że - zważywszy poddanie tej działalności prawotwórczej nadzorowi ze względu na kryterium legalności - trudno uznać, aby Prezes Rady Ministrów w tej procedurze uzgodnieniowej mógł sięgnąć po inne kryterium niż legalność, tym samym więc rozwiązanie to nie spełnia żadnej merytorycznie uzasadnionej funkcji. Powyższe spostrzeżenie można odnieść również do uzgodnienia projektu statutu związku komunalnego z wojewodą, w której to procedurze szczególnie ostro widać, że mamy tu do czynienia ze swoistym dublowaniem działań wojewody, który badając projekt statutu związku, działa ex ante, a następnie badając w trybie nadzoru już uchwalony statut, działa ex post. Można więc postawić tezę, że powyższa regulacja, nie przynosząc wymiernych korzyści, nie spełnia bowiem wyraźnej funkcji merytorycznej, z całą pewnością może przynosić szkody, może bowiem powodować wydłużenie procedury uchwalania statutu związku, a tym samym procedury utworzenia związku. Warto też zaznaczyć, że odesłanie do odpowiednich przepisów dotyczących rozstrzygnięcia nadzorczego dotyczącego jednostek samorządu lokalnego sprawia, że stanowisko wojewody w sprawie projektu statutu związku może być zaskarżone do sądu administracyjnego z powodu niezgodności z prawem ${ }^{35}$.

Prezentowana w doktrynie ocena tego rozwiązania w kontekście samodzielności jednostek samorządu terytorialnego (gmin) nie jest jednolita. Jest wyrażany pogląd uznający powyższe rozwiązanie za wyjątek od reguły wolności statutowej gminy, niełamiący zasady sa-

${ }^{34}$ W. Kisiel, Art. 3 [w:] Ustawa..., red. P. Chmielnicki, s. 85. Brakuje natomiast argumentów na rzecz prezentowanego w doktrynie poglądu, że wprowadzenie wymogu uzgadniania projektu statutu służy gwarancji znaczenia, jakie z punktu widzenia właściwej realizacji zadań publicznych ma prawidłowa organizacja ustroju wewnętrznego dużego miasta. Por. bliżej Ł. Złakowski, Art. 3 [w:] Ustawa o samorządzie gminnym. Komentarz $z$ odniesieniami do ustaw o samorzadzie powiatowym i samorzadzie województwa, red. R. Hauser, Z. Niewiadomski, Warszawa 2011, s. 22.

${ }^{35} \mathrm{~W}$ tym stanie rzeczy trudno uznać, aby ustawodawcy udało się osiągnąć cele zamierzone przez projektodawcę ustawy o samorządzie gminnym oraz niektórych innych ustaw wyrażone w uzasadnieniu projektu tej ustawy, a polegające m.in. na zwiększeniu samodzielności i elastyczności działania jednostek samorządu terytorialnego czy ułatwieniu współpracy tych jednostek - uzasadnienie rządowego projektu ustawy o zmianie ustawy o samorządzie gminnym oraz o zmianie niektórych innych ustaw, VII kadencja, druk sejm. nr 2656. 
modzielności ${ }^{36}$. Podzielić należy powyższy pogląd z jednoczesnym zastrzeżeniem, że choć nie mamy tu do czynienia z łamaniem zasady samodzielności jednostek samorządu lokalnego, to jednak mamy do czynienia z nieuzasadnionym jej ograniczeniem ${ }^{37}$. Natomiast w pełni podzielić należy formułowany w doktrynie pogląd o braku racjonalnego uzasadnienia dla przyjętego rozwiązania włączającego Prezesa Rady Ministrów - poza określonymi w art. 96 i 97 u.s.g. szczególnymi przypadkami w sferze ad personam - do nadzoru nad procedurą stanowienia statutu gminy ${ }^{38}$. Natomiast niewątpliwa odrębność związku metropolitalnego wyrażająca się w tym, że jest on tworzony nie przez gminy, ale przez Radę Ministrów, wymaga odrębnego spojrzenia na miejsce Prezesa Rady Ministrów w procedurze ustanawiania jego statutu, który nie podlega nadzorowi administracyjnemu nad samorządem terytorialnym. Można uznać, że w tej sytuacji Prezes Rady Ministrów będzie sprawował nadzór $e x$ ante nad ustanawianiem statutu związku metropolitalnego.

Natomiast nie ulega wątpliwości, że sfera samodzielności jednostek samorządu-uczestników związku metropolitalnego województwa śląskiego jest poważnie ograniczona. Nie decydują one o podjęciu współdziałania w tej formie, nie decydują w sposób bezpośredni o swoim uczestnictwie w tym związku (formułują jedynie swoją opinię w ramach konsultacji z mieszkańcami przed utworzeniem związku), nie mają wpływu na zakres zadań realizowanych przez ten związek, nie mają też żadnego wpływu na treść statutu związku metropolitalnego. Jedynie w niewielkim zakresie, bo w odniesieniu do spraw organizacyjnych dotyczących władz związku jednostki samorządu-uczestnicy związku dysponują sferą samodzielności.

${ }^{36}$ A. Wiktorowska, Prawne..., s. 88.

37 Jak słusznie wskazywał w swym wyroku z 12.03.2007 r., K 54/05, OTK-A 2007/3, poz. 25, Trybunał Konstytucyjny, „wszelka ingerencja w sferę samodzielności jednostek samorządu terytorialnego musi być zgodna z zasadą proporcjonalności”, tymczasem w przedmiotowej sprawie ta zasada jest naruszona, bo wspomniane ograniczenia, poza niewątpliwym spowolnienia procedury tworzenia statutu związku, niczemu pozytywnemu nie służą.

38 W. Kisiel, Art. 3 [w:] Ustawa..., red. P. Chmielnicki, s. 85. 
Samodzielność jednostek samorządu jest względna, co oznacza, że może być ona - na podstawie ustaw i w ich granicach - ograniczana. Analizując ten problem w odniesieniu do jednostek samorządu-uczestników związków (zarówno związków komunalnych, jak i związku metropolitalnego), należy zauważyć, że generalnie (poza wskazanymi wyżej wyjątkami w zakresie ustalania ustrojowych podstaw związku komunalnego) mamy do czynienia z uzasadnionym merytorycznie ograniczaniem sfery samodzielności, gdyż owo ograniczenie jest racjonalnie uzasadnione, służy osiągnięciu pewnej wartości, jaką w przypadku związku metropolitalnego jest niewątpliwie potrzeba realizacji zadań metropolitalnych, czyli zadań wspólnych dla całego szeroko rozumianego funkcjonalnego zespołu miejskiego występującego obiektywnie, a więc niezależnie od tego, czy znajduje on odzwierciedlenie w istniejących strukturach ustrojowych zarządu lokalnego i w aktualnym podziale terytorialnym ${ }^{39}$. Wydaje się, że wskazywany obiektywizm istnienia miejskiego zespołu funkcjonalnego w pełni legitymizuje również włączenie do związku metropolitalnego tych gmin, których rady nie wydały pozytywnej opinii w tym przedmiocie.

\section{Bibliografia:}

Adamiak B., Statut gminy, ST 1993/7-8

Adamiak B., Uwagi o samodzielności organu samorzadu terytorialnego $w$ ksztattowaniu treści rozstrzygnięcia sprawy indywidualnej decyzja administracyjna [w:] Aktualne problemy funkcjonowania samorzadu terytorialnego, red. E. Ura, E. Feret, S. Pieprzny, Sandomierz-Rzeszów 2017

Bandarzewski K., Art. 64 [w:] Ustawa o samorządzie gminnym. Komentarz, red. P. Chmielnicki, Warszawa 2013

Biernat S., Działania wspólne w administracji państwowej, Ossolineum 1979 Bojanowski E., Samodzielność wspólnot samorządowych wewnątrz systemu samorządu terytorialnego [w:] Granice samodzielności wspólnot samorządowych, red. E. Ura, Rzeszów 2005

${ }^{39}$ B. Dolnicki, Koncepcja powiatu metropolitalnego „Administracja. Teoria. Dydaktyka. Praktyka” 2011/4, s. 35. 
Borkowski J., Uprawnienia organu samorządu terytorialnego współdziałającego przy wydawaniu decyzji, „Jurysta” 1995/1

Borkowski J., Współdziałanie organów administracji państwowej przy wydawaniu indywidualnych decyzji administracyjnych, „Zeszyty Naukowe Uniwersytetu Łódzkiego" 1963/31

Dawidowicz W., Wstęp do nauk prawno-administracyjnych, Warszawa 1974

Dolnicki B., Koncepcja powiatu metropolitalnego, „Administracja. Teoria. Dydaktyka. Praktyka" 2011/4

Dolnicki B., Samorzad terytorialny, Warszawa 2016

Dolnicki B., Cybulska R., Nowe dwustronne formy działania administracji publicznej - zagadnienia wybrane [w:] Koncepcja systemu prawa administracyjnego. Zjazd Katedr Prawa Administracyjnego i Postęowania administracyjnego, Zakopane 24-27 września 2006 r., red. J. Zimmermann, Warszawa 2007

Dolnicki B., Marchaj R., Związek metropolitalny w województwie śląskim, ST 2017/7-8

Grala A., Wpływ władz miejskich i gminnych na kompleksowy rozwój ich terenu, „Problemy Rad Narodowych” 1979/44

Grążawski M., Małecka-Łyszczek M., Związek jako forma współdziałania jednostek samorzadu terytorialnego [w:] Jednostka, państwo, administracja - nowy wymiar. Międzynarodowa konferencja naukowa Olszanica, 23-26 maja 2004 r., red. E. Ura, Rzeszów 2004

Jaworska-Dębska B., Glosa do wyroku NSA z 12.07.2006 r. (II OSK 571/06, niepubl.), „Przegląd Prawa Publicznego” 2007/6

Jaworska-Dębska B., Współdziałanie organów samorządu terytorialnego przy wydawaniu decyzji administracyjnych [w:] Prawo administracja obywatele. Profesorowi Eugeniuszowi Smoktunowiczowi, red. A. Jamróz, Białystok 1997 Jaworska-Dębska B., Współdziałanie organów władzy i administracji państwowej $z$ organizacjami społecznymi $w$ dziedzinie kultury fizycznej i turystyki, „Problemy Rad Narodowych" 1987/70

Kisiel W., Art. 3 [w:] Ustawa o samorzadzie gminnym. Komentarz, red. P. Chmielnicki, Warszawa 2013

Kisiel W., Sądowa kontrola i ochrona samorzadu terytorialnego [w:] Prawo samorzadu terytorialnego $w$ Polsce, red. W. Kisiel, Warszawa 2006

Kledzik P., Wspótdziałanie jednostek samorządu terytorialnego w zakresie stanowienia i stosowania prawa [w:] Formy współdziałania jednostek samorządu terytorialnego, red. B. Dolnicki, Warszawa 2012

Korczak J., Statuty jednostek samorzadu terytorialnego, ST 2000/5

Lang J.M., Współdziałanie administracji ze społeczeństwem, Warszawa 1985 
Leoński Z., Formy współdziałania w samorzq̨dzie terytorialnym, ST 1995/4

Łazutka P., 25 lat współdziałania jednostek samorządu terytorialnego $w$ Polsce $w$ formie związku celowego. Analiza obecnego stanu prawnego i postulaty de lege ferenda [w:] Prawne problemy samorzadu terytorialnego z perspektywy 25-lecia jego funkcjonowania, red. B. Jaworska-Dębska, R. Budzisz, Warszawa 2016

Mączyński M., Samodzielność a samorządność [w:] Nadzór nad samorządem a granice jego samodzielności, red. M. Stec, M. Mączyński, Warszawa 2011

Niewiadomski Z., Współdziałanie komunalne [w:] System Prawa Administracyjnego, t. 6, Podmioty administrujące, red. R. Hauser, Z. Niewiadomski, A. Wróbel, Warszawa 2011

Ofiarska M., Formy publicznoprawne współdziałania jednostek samorządu terytorialnego, Warszawa 2008

Samorzad terytorialny $w$ Polsce, red. J.P. Tarno, Warszawa 2002

Skrzydło-Niżnik I., Model ustroju samorządu terytorialnego w Polsce na tle zagadnień ustrojowego prawa administracyjnego, Kraków 2007

Stahl M., Niepubliczne podmioty administrujące [w:] System Prawa Administracyjnego, t. 6, Podmioty administrujące, red. R. Hauser, Z. Niewiadomski, A. Wróbel, Warszawa 2011

Stahl M., Samorząd terytorialny a państwo, „Studia Prawno-Ekonomiczne” 1992/46

Świątkiewicz J., Z problematyki współdecyzji organów w prawie administracyjnym, PiP 1964/5-6

Wierzbowski M., Współdziałanie rad narodowych z organizacjami społecznymi, „Gospodarka i Administracja Terenowa” 1971/4

Wiktorowska A., Prawne determinanty samodzielności gminy. Zagadnienia administracyjnoprawne, Warszawa 2002

Zimmermann J., Prawo administracyjne, Warszawa 2016

Złakowski Ł., Art. 3 [w:] Ustawa o samorzadzie gminnym. Komentarz z odniesieniami do ustaw o samorządzie powiatowym i samorządzie województwa, red. R. Hauser, Z. Niewiadomski, Warszawa 2011 